\title{
Investigation of the antimycobacterial activity of 36 plant extracts from the brazilian Atlantic Forest
}

\author{
Daniela Fernandes Ramos ${ }^{1}$, Gilda Guimarães Leitão ${ }^{2}$, Fernanda das Neves Costa ${ }^{2}$, Lisandra \\ Abreu$^{2}$, Javier Vargas Villarreal ${ }^{3}$, Suzana Guimarães Leitão ${ }^{2}$, Salvador Luis Said y Fernández ${ }^{3}$, \\ Pedro Eduardo Almeida da Silva ${ }^{1 *}$
}

'Laboratório de Micobactérias, Departamento de Patologia, Universidade Federal do Rio Grande do Sul, ${ }^{2}$ Núcleo de Pesquisas de Produtos Naturais, Universidade Federal do Rio de Janeiro, ${ }^{3}$ Instituto Mexicano Del Seguro Social, Centro de Investigación Biomédica del Noreste

*Correspondência:

P. E. A. Silva

Laboratório de Micobactérias Departamento de Patologia

Universidade Federal do Rio Grande Rua General Osório, s/n - Área Acadêmica da Saúde

96200-190 - Rio Grande do Sul - RS, Brasil

E-mail: pedre@furg.br

\begin{abstract}
Thirty-six plant extracts from the brazilian Atlantic Forest were tested for their antimycobacterial activity against Mycobacterium tuberculosis $H_{37} R v$ and M. kansasii, using the method REMA in seriate concentrations of 100 to $0.20 \mu \mathrm{g} / \mathrm{mL}$. Among the thirty six extracts tested, five were active against $\mathrm{M}$. tuberculosis, and three of these extracts also showed activity against $\mathrm{M}$. kansasii. Cytotoxicity test with VERO cells was performed with the five extracts active against M. tuberculosis. Only the extract of Peschiera affinis was identified as non-toxic in the concentration of $100 \mu \mathrm{g} / \mathrm{mL}$.
\end{abstract}

\author{
Uniterms \\ - Mycobacterium \\ tuberculosis \\ - Mycobacterium kansasii \\ - Plant extracts/ \\ antimycobacterial activity \\ - Antimycobacterials \\ - Cytotoxicity
}

\section{INTRODUCTION}

Tuberculosis (TB) is considered one of the main causes of death worldwide. There were nine million new TB cases and approximately two million TB deaths in 2004 (WHO, 2006). The available treatment requires a long lasting (at least six months) multi-drug scheme, which causes difficulties to the patient's adhesion. Furthermore the available drugs do not assure the sterilization of the lesion, being possible that, in spite of the clinical cure the bacillus stays in latent state inside the macrophages. Associated to these factors is the increase of the number of cases of TB with resistant and multi-drug resistant (MDR) strains and the insufficient therapeutic arsenal available for the treatment, which stimulates the development of new antiTB drugs (Silva et al., 2006).

In addition to that, some species of non-tuberculous mycobacteria (NTM) have increased their clinical importance in the last years. M. kansasii causes both pulmonary and extra-pulmonary diseases and ranked second behind Mycobacterium avium complex as the most common MNT infections (Graybill, Bocanegra, 2001; Telles et al., 2005). The current treatment of pulmonary diseases caused by M. kansasii in non-HIV-infected patients includes isoniazid, rifampicin and ethambutol. Nevertheless, alternative drugs have been proposed for patients infected with $M$. kansasii resistant to rifampicin and AIDS patients treated with HIV protease inhibitors, since rifampicin accelerates the hepatic metabolism of these drugs, rendering them potentially ineffective (Guna et al., 2005).

Since ancient times, natural products notably those from plant origin, have consistently been an important source of therapeutic agents. Currently, about $25-30 \%$ of all drugs available as therapeutics are derived from natural products (plants, microbes and animals). In spite of that, in the last decades, due mainly to the advance of combinatorial chemistry, research into natural products in 
the pharmaceutical industry has experienced a slow decline (Calixto, 2005; Newman et al., 2003). The search for new pharmacologically active agents obtained by screening natural sources such as microbial and plant extracts has led to the discovery of many clinical useful drugs that play a major role in the treatment of human diseases (Shu, 1998).

Several compounds with antimycobacterial activity have been found among plants, fungi and marine organisms (Lewis, 1999; Pauli et al., 2005). Over 350 natural products, mainly plant species, which have been used in traditional medicine, have been assessed for their antimycobacterial activities (Newton et al., 2000). A number have been shown to demonstrate significant in vitro antimycobacterial activities and active plant-derived compounds belonging to various chemical classes have been isolated. These findings have therefore stimulated further search towards the isolation of new antimycobacterial agents from natural products (Newton $e t$ al., 2002). This products form one avenue in the search for new antitubercular agents, with many groups undertaking screening of natural product extracts as the preliminary step to finding new lead compounds, as for combinations of cost, health and throughput issues, there are a wide range of mycobacterial test organisms and biological assay methodologies utilized in current day antimycobacterial drug discovery (Copp, 2003).

Likewise, different kinds of studies on the mechanisms of action, interactions with antibiotics or other medicinal plants or compounds, and the pharmacokinetic profile of the extracts should be given high priority (Ríos, Recio, 2005).

Natural products chemistry is a research area with unlimited potential, important to countries rich in plant species and which are abundant in native vegetation like Brazil. This country is one of the two richest countries on earth in terms of biodiversity and has two of the 25 world's hotspots threatened of disappear (Mittermeier et al., 1998). The Atlantic Forest region ranks among the top five of these hotspots and only $7.5 \%$ of the original extent of the Atlantic Forest remain intact. Given the fast devastation of the environment the screening of plant secondary metabolites for the search of biological activities becomes an urgent task (Calixto, 2005).

In this study we evaluated the antimycobacterial activity of 36 plant extracts belonging to 19 different botanical families (Anacardiaceae, Apocynaceae, Bignoniaceae, Bombacaceae, Caesalpiniaceae, Euphorbiaceae, Fabaceae, Flacourtiaceae, Lecythidaceae, Mimosaceae, Meliaceae, Moraceae, Myristicaceae, Nyctaginaceae, Rubiaceae, Rutaceae, Sapotaceae, Siparunaceae, Tiliaceae) selected from the Atlantic Forest.

\section{MATERIALS AND METHODS}

\section{Plant material}

Plants were collected from two Atlantic Forest fragments (Bela Fama Forest - Santana do Deserto city, MG and Boa Vista Forest - Levy Gasparian city, RJ), Brazil. Taxonomic identifications were done by Sebastião J. da Silva Neto from Instituto de Pesquisas Jardim Botânico do Rio de Janeiro, Brazil. Voucher specimens are deposited at the Herbarium of the Federal University of Rio de Janeiro.

\section{Preparation of extracts}

The air-dried and powdered leaves (20 g of each) were exhaustively extracted with ethanol $96^{\circ} \mathrm{GL}$. The obtained extracts were filtered and evaporated under reduced pressure on a rotary evaporator.

\section{Isolates and strain preparation}

The antimicrobial activity of the extracts was evaluated against $M$. tuberculosis $\mathrm{H}_{37} \mathrm{Rv}$ (ATCC 27294) and M. kansasii (ATCC 12478) maintained on Ogawa medium for about 14 days. The bacterial suspensions were prepared in sterile water containing beads of glass of $3 \mathrm{~mm}$. The suspension was homogenized by vortex agitation and the turbidity was adjusted in agreement with tube one of the scale of McFarland $\left(3,2 \times 10^{6} \mathrm{cfu} / \mathrm{mL}\right)$. The inoculum was prepared diluting the bacterial suspension in the proportion of $1: 25$ in medium $7 \mathrm{H} 9$ broth $(4.7 \mathrm{~g}$ of Middlebrook $7 \mathrm{H} 9$ broth base [Difco - Becton Diskinson], $2 \mathrm{~mL}$ of glycerol [Vetec ltda.] in $900 \mathrm{ml}$ water) enriched with $10 \%$ oleic acid, albumin, dextrose and catalase (OADC -BBL) (Franzblau et al., 1998).

\section{Evaluation of the antimycobacterial activity of the extracts}

The method used for the determination of the antimycobacterial activity was the REMA (Palomino et al., 2002). The screening assay was, in brief, accomplished in microplates (96 wells) using the resazurin as indicator of cellular viability. Seventy-five microlitres of medium $7 \mathrm{H} 9$ enriched with $10 \%$ OADC was used in each well, after was added $75 \mu \mathrm{L}$ of the extracts were weighted dissolved in DMSO at a concentration of $100 \mu \mathrm{g} / \mathrm{mL}$ and $75 \mu \mathrm{L}$ of the Mycobacterium inoculum. The Minimal Inhibitory Concentration (MIC) was determined for extract serial dilutions (starting for $100 \mu \mathrm{g} / \mathrm{mL}$ ) using $100 \mu \mathrm{L}$ of medium 
7H9, $100 \mu \mathrm{L}$ of extract and $100 \mu \mathrm{L}$ of inoculum. The MIC was did just for those extracts presenting antimycobacterial activity at $100 \mu \mathrm{g} / \mathrm{mL}$ in the screening assay. We establish MIC $100 \mu \mathrm{g} / \mathrm{mL}$ as active because the MIC of a crude natural extract may or may not be a reliable indicator of the chances for success in isolating a potent antimycobacterial agent from that extract. The possibility exists that (i) an extract with a relatively low MIC (high activity) may contain large quantities of only very few moderately active major constituents, while (ii) moderately active crude materials could lead to minor compounds with high activity (Pauli et al., 2005).

\section{Cytotoxicity assay}

The citototoxicity of the extracts with antimycobacterial activity were determined with VERO cells (Case et al., 2006). Concisely, the VERO cells were cultivated at $37^{\circ} \mathrm{C}$ in a humid atmosphere with $5 \% \mathrm{CO}_{2}$ (Sánchez et al., 2002) in modified DMEM medium (10,4 g DMEM, $900 \mathrm{ml}$ water MilliQ, 2,0g $\mathrm{NaHCO}_{3}$ - Sigma D5671) complemented with 10\% Bovine Fetal Serum (FCS), in order to obtain about 1 to $2 \times 10^{5}$ cell $/ \mathrm{mL}$ (Sivropoulou et al., 1997). The extracts were serial diluted (1:2) from an initial concentration of $100 \mu \mathrm{g} / \mathrm{ml}$ to a final concentration of $3 \mu \mathrm{g} / \mathrm{mL}$. The number of cells was determined in a Neubauer's chamber, while the percentage of viable cells, was measured with trypan blue. Statistical analysis to determine $\mathrm{LD}_{50}$ was accomplished through the PROBIT method.

\section{RESULTS AND DISCUSSION}

Thirty six plant extracts from the Brazilian Atlantic Forest (Anadenanthera colubrina, Aparisthmium cordatum, Apuleia leiocarpa, Astronium fraxinifolium, Bathysa australis, Bombacopsis stenopetala, Brosimum guianense, Cariniana estrellensis, Carpotroche brasiliensis, Casearia sylvestris, Cedrela fissilis, Croton floribundus, Dalbergia nigra, Ficus gomelleria, Guapira opposita, Guettarda virburnoides, Luehea grandiflora, Mabea fistulifera, Malouetia arborea, Melanoxylon brauna, Pera heteranthera, Pera leandri, Peschiera affinis, Piptadenia gonoacantha, Plathymenia foliolosa, Pouteria filipes, Psychotria vellosiana, Senifeldera multiflora, Simira glaziovii, Simira sampaioana, Siparuna guianensis, Siparuna reginae, Sorocea bonplandii, Sparattosperma leucanthum, Zanthoxylum rhoifolium, Virola oleifera) were tested for their antimycobacterial activity at the concentration of $100 \mu \mathrm{g} / \mathrm{mL}$ in order to select the most active ones (Table I). Five extracts: Psychotria vellosiana; Pouteria filipes, Cedrela fissilis, Plathymenia foliolosa and Peschiera affinis were active against $M$. tuberculosis with MIC between 0.2 and $3.12 \mu \mathrm{g} / \mathrm{mL}$ (Table II). Concerning $M$. kansasii, three of these extracts (Cedrela fissilis, Plathymenia foliolosa and Peschiera affinis) were also active, however with MIC $100 \mu \mathrm{g} / \mathrm{mL}$ (Table II). Other ten extracts were active only against $M$. kansasii: with MIC of the $100 \mu \mathrm{g} / \mathrm{mL}$ (Siparuna arianeae (Siparunaceae); Guettarda virburnoides (Rubiaceae); Cariniana estrellensis (Lecythydaceae); Sparattosperma leucanthum (Bignoniaceae); Brosimum guanense (Moraceae)), $50 \mu \mathrm{g} / \mathrm{mL}$ (Siparuna reginae (Siparunaceae); Piptadenia gonoacantha (Fabaceae); Ficus gomelleria (Moraceae)); $25 \mu \mathrm{g} / \mathrm{mL}$ (Aparisthmium cordatium (Euphorbiaceae)) and $1,56 \mu \mathrm{g} / \mathrm{mL}$ (Senifildera multiflora (Euphorbiaceae)). The five extracts active against $M$. tuberculosis belong to plants used in Brazilian Folk Medicine (1, 3, 10, 12). Even though a larger number of extracts showed activity against $M$. kansasii, in general, their MIC were higher than those for $M$. tuberculosis (Table II). In fact, environment microorganisms show a higher level of natural resistance than classical pathogens.

The cytotoxicy of the five extracts active against $M$. tuberculosis was evaluated showing that one (Peschiera affinis) was not toxic to VERO cells in the concentration of $458 \mu \mathrm{g} / \mathrm{mL}$ (Figure 1). The extract of Peschiera affinis, besides not being toxic for the VERO cells in a higher concentration, also presented a low MIC against $M$. tuberculosis.

The presence of indol alkaloids, commonly found in plants of the families Rubiaceae and Apocynaceae (Schripsema et al., 2003) could explain the activity of the extracts of Psychotria vellosiana and Peschiera affinis

TABLE I - MIC of active extracts of the Atlantic forest against to M. tuberculosis and M. kansasii

\begin{tabular}{|c|c|c|c|c|c|c|c|c|}
\hline & \multicolumn{8}{|c|}{$\mathrm{N}^{\circ}$ of the extracts with MIC of the $(\mu \mathrm{g} / \mathrm{mL})$} \\
\hline & 0.20 & 0.78 & 1.56 & 3.12 & 25 & 50 & 100 & $>100 *$ \\
\hline M. tuberculosis & 2 & 2 & & 1 & & & & 31 \\
\hline M. kansasii & & & 1 & & 1 & 3 & 8 & 23 \\
\hline
\end{tabular}

\footnotetext{
* No active extract.
} 

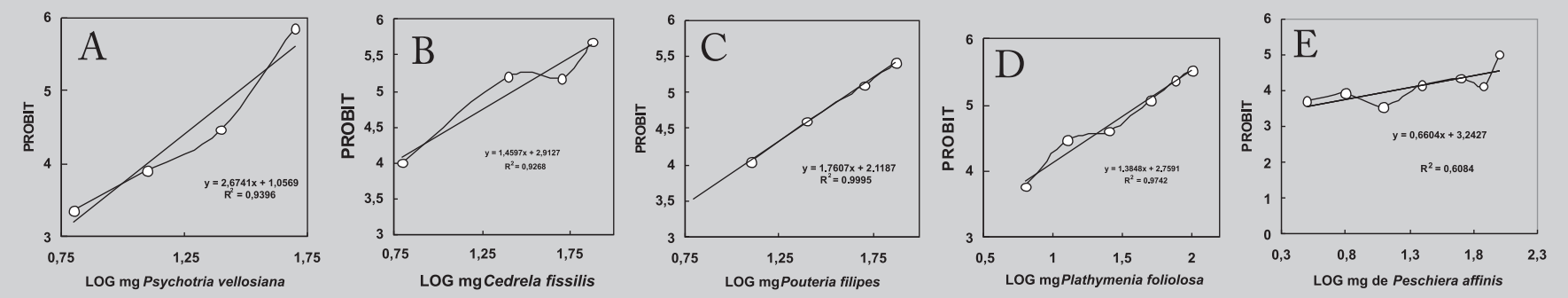

FIGURE 1 - Cytotoxicity graphs, (A) Cytotoxicity test of Psychotria vellosiana, (B) Cytotoxicity test of Cedrela fissilis, (C) Cytotoxicity test of Pouteria filipes, (D) Cytotoxity test of Plathymenia foliolosa, (E) Cytotoxicity test of Peschiera affinis.

TABLE II - Results of MIC of five vegetable extracts of the Atlantic forest against to M. tuberculosis and M. kansasii

\begin{tabular}{lcc}
\hline & M. tuberculosis & M. kansasii \\
\hline $\begin{array}{l}\text { Psychotria vellosiana } \\
\text { (Rubiaceae) }\end{array}$ & $\leq 0.20 \mu \mathrm{g} / \mathrm{mL}$ & $>100 \mu \mathrm{g} / \mathrm{mL}$ \\
$\begin{array}{l}\text { Cedrela fissilis } \\
\text { (Meliaceae) }\end{array}$ & $3.12 \mu \mathrm{g} / \mathrm{mL}$ & $100 \mu \mathrm{g} / \mathrm{mL}$ \\
$\begin{array}{l}\text { Pouteria filipes } \\
\text { (Sapotaceae) }\end{array}$ & $0.78 \mu \mathrm{g} / \mathrm{mL}$ & $>100 \mu \mathrm{g} / \mathrm{mL}$ \\
$\begin{array}{l}\text { Plathymenia foliolosa } \\
\text { (Fabaceae) }\end{array}$ & $0.78 \mu \mathrm{g} / \mathrm{mL}$ & $100 \mu \mathrm{g} / \mathrm{mL}$ \\
$\begin{array}{l}\text { Peschiera affinis } \\
\text { (Apocynaceae) }\end{array}$ & $\leq 0.20 \mu \mathrm{g} / \mathrm{mL}$ & $100 \mu \mathrm{g} / \mathrm{mL}$ \\
\hline
\end{tabular}

against mycobacteria. Phytochemical analyses of plants of the genus Psychotria demonstrated the presence of psychotridines, which have been associated with dosedependent analgesic effects (Amador et al., 2001). Peschiera affinis as well as other Apocynaceae plants are used in northeast Brazil as antitumoral and spasmolytic drugs (Miranda et al., 2003).

The family Maliaceae, represented in this study by Cedrela fissilis presents modified triterpenes (limonoids) and inhibitory activity has been demonstrated in the enzyme Leishmania APRT (Adenine Phosphoribosyl Transferase), present also in M. tuberculosis genome (Ambrozin et al., 2005). This enzyme has an important function in the pathway of purine salvation, which turns this enzyme an interesting target to antimicrobial agents (Zottis et al., 2006).

Recently, an extract of Plathymenia foliolosa showed antimicrobial activity against $E$. coli (Alves, 2000), allowing to infer that this plant could be active against other microorganisms.

These results suggest that Peschiera affinis has active compounds against $M$. tuberculosis and $M$. kansasii which are not toxic to human cells. Further purification studies on the extract of this plant are being carried out in order to identify the active compounds.

\section{RESUMO}

\section{Análise da atividade antimicobacteriana de 36 extra- tos vegetais da Mata Atlântica brasileira}

Trinta e seis extratos vegetais originários da Mata Atlântica foram testados quanto à sua atividade antimicobacteriana frente ao M. tuberculosis $H_{37} R v$ e M. kansasii, utilizando o método REMA em concentrações seriadas de 100 a 0,20 $\mu \mathrm{g} / \mathrm{mL}$. Dentre os trinta e seis extratos testados, cinco mostraram atividade frente ao $\mathrm{M}$. tuberculosis, e destes apenas, três mostraram atividade ao M. kansasii, que apresentou susceptibilidade a outros dez. O teste de citotoxicidade com células VERO foi realizado com os cinco extratos ativos frente ao $\mathrm{M}$. tuberculosis em que identificou-se a não toxicidade em apenas um extrato (Peschiera affinis) na concentração de $100 \mu \mathrm{g} / \mathrm{mL}$.

UNITERMOS: Mycobacterium tuberculosis. Mycobacterium kansasii. Extratos vegetais/atividade antimicobacteriana. Antimicobacterianos. Citotoxicidade.

\section{REFERENCES}

ALVES, T.M.A.; SILVA, A.F.; BRANDÃO, M.; GRANDI, T.S.M.; SMÂNIA,E.F.; JÚNIOR, A.S.; ZANI, C.L. Biological Screening of Brazilian Medicinal Plants. Mem. Inst. Oswaldo Cruz, v.95, n.3, p.367-373, 2000.

AMADOR, T.A.; VEROTTA, L.; NUNES, D.S.; ELISABETSKY, E. Involvement of nmda receptors in the analgesicproperties of psychotridines. Phytomedicine, v.8, n.3, suppl.5, p.202-206, 2001. 
AMBROZIN,A.R.; LEITE,A.C.; SILVA, M.; VIEIRA, P.C.; FERNANDES, J.B.; THIEMANN, O.H.; DA SILVA, M.F.; OLIVA, G. Screening of LeishmaniaAPRT enzyme inhibitors. Pharmazie, v.60, n.10, p.781-784, 2005.

CALIXTO, J.B. Twenty-five years of research on medicinal plants in Latin America: A personal view. $J$. ethnopharmacol., v.100, n. p.131-134, 2005.

CASE, R.J.; FRANZBLAU, S.G.; WANG, Y.; CHO, S. H.; SOEJARTO, D.D.; PAULI, G.F. Ethnopharmacological evaluation of the informant consensus model on antituberculosis claims among the Manus. $J$. ethnopharmacol., v.106, n.1, p.82-89, 2006.

COPP, B.R. Antimycobacterial natural products. Nat. prod. rep., v.20, n. p.535-557, 2003.

FRANZBLAU, S.G.; WITZIG, R.S; MCLAUGLHLIN, J.C.; TORRES, P.; MADICO, G.; HERNANDEZ, A.; DEGNAN, M.T.; COOK, M.B.; QUENZER, V.K.; FERGUSON, R.M.; GILMAN, R.H. Rapid, LowTechnology MIC Determination with Clinical Mycobacterium tuberculosis Isolates by Using the Microplate Alamar Blue Assay. J. Clin. Microbiol., v.36, n.2, p.362-366, 1998.

GRAYBILL, R.J.; BOCANEGRA, R. Treatment alternatives for Mycobacterium kansasii. J. antimicrob. chemother, v.47, p.417-420, 2001.

GUNA, R.; MUÑOZ, C.; DOMINGUEZ, V.; GARCÍAGARCÍA, A.; GALVEZ, J.; JULIAN-ORTIZ, J.V.; BORRÁS, R. In vitro activity of linezolid, clarithromycin and moxifloxacin against clinical isolates of Mycobacterium kansasii. J. Antimicrob. Chemother, v.55, n. p.950-953, 2005.

KUETE, V.; TANGMOUO, J.G.; BENG, V.P.; NGOUNOU, F.N.; LONTSI, D. Antimicrobial activity of the methanolic extract from the stem bark of tridesmostemon omphalocarpoides (Sapotaceae). J. Ethnopharmacol., v.104, n. p.05-11, 2006.

LEWIS, K. Multidrug resistance: Versatile drug sensors of bacterial cells. Curr. biol., v.9, n. p.R403-R407, 1999.

MA, J.; YANG, H.; BASILE, M. J.; KENNELY, E.J. Analysis of Polyphenolic antioxidants ion monitoring liquid chromatography-mass spectrometry. J.Agric. Food Chem., v.52, n. p.5873-5878, 2004.
MIRANDA, R.P.; TAKETA, A.T.C.; VERA, R.A.V. Alucinógenos naturais: etnobotânica e psicofarmacologia. In: SIMÕES, C. M. O.; SCHENKEL, E. P.; GOSMANN, G.; MELLO, J. C. P; MENTZ, L.A.; PETROVICK, P.R. Farmacognosia: da planta ao medicamento. 5. ed. Porto Alegre/Florianópolis: Editora UFRGS/Editora da UFSC, 2003. Cap. 36, p.918-958.

MITTERMEIER, R.; BOWLES, I.; KONSTANT, W. Biodiversity hotspots revealed. People Planet, v.7, n.4, p.10-15, 1998.

NEWMAN, D.J.; GORDON, M.G.; KENNETH, M.S. Natural products as sources of new drugs over the period 1981-2002. J. Nat. Prod, v.66, n.7, p.1022-1037, 2003.

NEWTON, S.M.; LAU, C.; WRIGHT, C.W. A review of antimycobacterial natural products. Phytother. Res., v.14, p.302-322, 2000.

NEWTON, S.M.; LAU, C.; GURCHA, S.S.; BESRA, G.S.; WRIGHT, C.W. The evaluation of forty-three plant species for in vitro antimycobacterial activities; isolation of active constituents from Psoralea corylifolia and Sanguinaria Canadensis. J. Ethnopharmacol., v.79, p.57-67, 2002.

PALOMINO, J.C.; MARTIN, A.; CAMACHO, M.; GUERRA, H.; SWINGS, J.; PORTAELS, F. Resazurin Microtiter Assay Plate: Simple and Inexpensive Method for Detection of Drug Resistance in Mycobacterium tuberculosis. Antimicrob. Agents Chemother., v.46, n.8, p.2720-2722, 2002.

PAULI, G.F.; CASE, R.J.; INUIT,T.; WANG,Y.; CHO, S.; FISCHER, N.H.; FRANZBLAU, S.G. New perspectives on natural products in TB drug research. Life Sci., v.78, n. p.485-494, 2005.

RÍOS, J. L.; RECIO, M.C. Medicinal plants and antimicrobial activity. J. Ethnopharmacol., v.100, n. p.80-84, 2005.

SÁNCHEZ, G.; CUELLAR, D.; ZULANTAY, I.; GAJARDO, M.; GONZÁLEZ-MARTIN, G. Cytotoxicity and trypanocidal activity of nifurtimox encapsulated in ethylcyanoparticles. Biol. Res., v.35, n. p.39-45, 2002. 
SCHRIPSEMA, J.; DAGNINO, D.; GOSMANN, G Alcalóides indólicos. In: SIMÕES, C. M. O.; SCHENKEL, E. P.; GOSMANN, G.; MELLO, J. C. P; MENTZ, L.A.; PETROVICK, P.R. Farmacognosia: da planta ao medicamento. 5. ed. Porto Alegre/Florianópolis: Editora UFRGS/Editora da UFSC, 2003. cap. 31.p. 918-958.

SHU, Y.Z. Recent natural products based drug development: A pharmaceutical industry perspective. J. Nat. Prod., v.61, n. p.1053-1071, 1998.

SILVA, P.A.; BOFFO, M.M.S.; MATTOS, I.G.; SILVA, A.B.S.; PALOMINO, J.C.; MARTIN, A.; TAKIFF, H.E. Comparison of redox and D29 phage methods for detection of isoniazid and rifampicin resistance in Mycobacterium tuberculosis. Clin. Microbiol. Infect., v.12, n.3, p.293-296, 2006.

SIVROPOULOU,A.; NIKOLAOU, C.; PAPANIKOLAOU, E.; KOKKINI, S.; LANARAS, T.; ARSENAKIS, M. Antimicrobial Cytotoxic, and antiviral activities of Salvia fructicosa essential oil. J. Agric.Ffood Chem., v.45, n.8, p.3197-3201, 1997.
TELLES, M.A.S.; CHIMARA, E.; FERROZOLI, L.; RILEY, L.W. Mycobacterium kansasii: antibiotic susceptibility and PCR-restriction analysis of clinical isolates. J. Med. Microbiol., v.54, p.975-979, 2005.

WORLD HEALTH ORGANIZATION. Report on global tuberculosis: control surveillance, planning, financing. Geneva, 2006. 6-7p.

ZOTTIS, A.; NICOLUCI, P; CARVALHO, M.S.; IMAMURA, P.M.; THIEMANN, O.H.; ANDRICOPULO, A.D.; OLIVA, G. Estudo de modelagem molecular de uma nova classe de inibidores da adenina fosforribosiltransferase de Leishmania tarentolae. In: REUNIÃO ANUAL DA SOCIEDADE BRASILEIRA DE QUÍMICA, 29., Águas de Lindóia, 2006. Programas e resumos. MD081. (CD-Rom).

Recebido para publicação em 13 de agosto de 2007 Aceito para publicação em 01 de agosto de 2008 